Prawne i ekonomiczne aspekty migracji, red. Magdalena Butrymowicz, Piotr Kroczek, Kraków 2016, s. 7-29 (Biblioteczka Prawa, 1).

DOI: http://dx.doi.org/10.15633/9788374385473.02

Magdalena Butrymowicz

UNIWERSYTET PAPIESKI JANA PAWŁA II W KRAKOWIE

\title{
Prawo imigracyjne Wielkiej Brytanii. Zarys problemu
}

Wielka Brytania jest obecnie krajem stanowiącym główny cel emigracji zarobkowej w Europie oraz ziemią obiecaną dla rzesz imigrantów ze Środkowej Azji i Północnej Afryki, a w szczególności z państw objętych konfliktami zbrojnymi czy kryzysem ekonomicznym. Wskazać należy, iż do 1994 roku Wyspy Brytyjskie nie stanowiły głównej destynacji imigracyjnej, wręcz przeciwnie: były krajem, z którego obywatele wyjeżdżali do innych państw Europy Zachodniej oraz do Stanów Zjednoczonych i Australii ${ }^{1}$. Powoli jednak zmiany polityczne w Azji i Afryce spowodowały, iż coraz więcej imigrantów z byłych kolonii brytyjskich zaczynało ubiegać się o azyl w Wielkiej Brytanii lub o nadanie im statusu uchodźcy². Dodatkowo otwarcie się Unii

1 G. Clayton, Textbook on immigration and asylum law, London 2014, s. 5.

2 M. Travers, The British immigration courts: A study of law and politics, Bristol 1999, s. 37-42. 
Europejskiej na kraje byłego bloku komunistycznego zapoczątkowało emigrację zarobkową z Europy Wschodniej i Środkowej.

\section{Dane statystyczne w przedmiocie imigracji do Wielliej Brytanii na przestrzeni ostatnich 10 lat}

Analiza danych Brytyjskiego Instytutu Migracyjnego pozwala na zaobserwowanie wyraźnej desynchronizacji w zakresie liczby imigrantów na przestrzeni ostatnich stu lat. Analitycy wskazują na powstawanie tak zwanych fal imigracyjnych. Zebrane dane statystyczne pokazują, iż w 2015 roku do Wielkiej Brytanii wyemigrowało 290 tys. osób, z tego 165 tys. stanowią obywatele Unii Europejskiej. Wśród tych osób około 96 tys. (około 58 proc.) miało zagwarantowaną pracę, zaś 69 tys. (około 42 proc.) przybyło w celu jej poszukiwania. W grudniu 2015 roku w Wielkiej Brytanii przebywało około 2 mln obywateli innych krajów Unii Europejskiej oraz 1,2 mln obywateli państw spoza Unii Europejskiej. W tym samym roku z wnioskiem o przyznanie wizy pracowniczej wystąpiło około 1920 osób, czyli o 4 proc. więcej niż w latach poprzednich. O przyznanie azylu w 2015 roku wystąpiło do rządu brytyjskiego 38878 osób, czyli statystycznie o 20 proc. więcej niż w latach poprzednich. W Wielkiej Brytanii osiedliło się najwięcej osób pochodzących z Erytrei, Iranu i Pakistanu - po około 3,5 tys. osób z każdego z tych krajów33.

Przedmiotowe dane wskazują zatem, iż w Wielkiej Brytanii rokrocznie osiedla się około 320 tys. osób, z czego większość pochodzi z krajów Europy kontynentalnej. W ostatnich latach znacznie wzrosła także liczba osób ubiegających się o azyl ze względu na sytuację

3 N. White, Migration statistics quarterly report: February 2016, London 2016, s. $1-4$. 
polityczną w ich kraju. Przedmiotowe dane statystyczne przełożyły się na nastroje polityczne w Wielkiej Brytanii (generalnie nastawienie przeciętnego obywatela do imigrantów jest negatywne), a co za tym idzie na zmianę prawa imigracyjnego w taki sposób, aby ograniczyć liczbę osób wjeżdżających i osiedlających się na stałe w Wielkiej Brytanii. Dodatkowo przyrost naturalny wśród imigrantów w ostatnim dziesięcioleciu był tak znaczny, iż, jak wynika z raportu niezależnych organizacji pozarządowych takich jak Migration Watch UK, 85 proc. dzieci, które urodziły się w Wielkiej Brytanii od 2000 roku, to dzieci imigrantów ${ }^{4}$. Przedmiotowe dane statystyczne wyraźnie obrazują, iż w niedługiej przyszłości więcej będzie w Wielkiej Brytanii obywateli wywodzących się z krajów azjatyckich i afrykańskich niż ludności etnicznej anglosaskiej. Większe miasta, takie jak Londyn czy Manchester, zamieszkuje obecnie większa liczba imigrantów zarobkowych niż rodowitych Brytyjczyków. Zmiana prawa imigracyjnego i zaostrzenie procedur imigracyjnych wydaje się zatem naturalną konsekwencją znacznego wzrostu liczby imigrantów przybywających do Wielkiej Brytanii z zamiarem osiedlenia się na stałe.

\section{Prawo imigracyjne Wielkiej Brytanii}

Na początku xx wieku na terenie Anglii, a następnie całej Wielkiej Brytanii, zrodził się wyraźny sprzeciw wobec pracowników przyjeżdżających $z$ innych krajów, którzy obniżali stawki za godzinę pracy oraz gotowi byli pracować $\mathrm{w}$ dużo gorszych warunkach niż obywatele Wielkiej Brytanii. Dodatkowo pojawił się argument, iż pracownicy $\mathrm{z}$ innych krajów stanowią element wywrotowy, bowiem roznoszą

4 Recent Population Growth, http://www.migrationwatchuk.org/key-topics/population (dostęp: 15.01.2016). 
choroby i w większości przypadków pochodzą ze świata przestępczego. Mając to na uwadze, rząd brytyjski w 1905 roku przyjął The Aliens Act ${ }^{5}$. W oparciu o tę ustawę została utworzona nowa służba publiczna $\mathrm{w}$ postaci oficerów imigracyjnych (immigration officers), których jednym z podstawowych uprawnień (zachowanym do dziś) było prawo do odmowy wjazdu na terytorium Wielkiej Brytanii cudzoziemcom ${ }^{6}$, którzy w ich ocenie nie byli pożądani. Przedmiotowa ustawa definiowała jako takie osoby, które: nie miały rodziny lub znajomych mogących udzielić im wsparcia finansowego; nie miały zagwarantowanej pracy; były chore umysłowo lub wymagały pomocy państwa w codziennej egzystencji. Do tej kategorii zaliczali się także ci, którzy byli już uprzednio wydaleni z Wielkiej Brytanii oraz osoby skazane lub o kryminalnej przeszłości ${ }^{7}$.

Kolejna z ustaw imigracyjnych - British Nationality and Status of Aliens $\mathrm{Act}^{8}$ - została wprowadzona w 1914 roku. Ustawa ta normowała kwestię obywatelstwa brytyjskiego poprzez przyjęcie w art. 1, iż obywatelem brytyjskim jest każde dziecko urodzone na terytorium kontrolowanym przez Wielką Brytanię lub którego ojciec ma obywatelstwo brytyjskie. Określono także warunki, jakie musiały spełniać osoby, które ubiegały się o uzyskanie obywatelstwa brytyjskiego poprzez naturalizację?.

5 H. Wray, The Aliens Act 1905 and the immigration dilemma, „Journal of Law and Society" Vol. 33, No. 2 (Jun., 2006), s. 302-323.

6 Oficerowie imigracyjni mieli swoje biura w portach określonych ustawą, zwanych portami imigracyjnymi, i na niektórych statkach mających licencję na transport cudzoziemców do Wielkiej Brytanii. An Act to amend the Law with regard to Aliens, 1905, 5 Edw.7, c. 13.

7 An Act to amend the Law with regard to Aliens, 1905, 5 Edw.7, c. 13.

8 British Nationality and Status of Aliens, 1914 [4\&5 GEO. 5. c. 17].

9 British Nationality and Status of Aliens, 1914 [4\&5 GEO. 5. c. 17]. 
W 1919 roku uchwalony został Aliens Restriction Act ${ }^{10}$, który przyznawał poszczególnym organom władzy wykonawczej szereg uprawnień w zakresie ekstradycji i ograniczania wjazdu na teren Wielkiej Brytanii. Stanowił on uzupełnienie i rozszerzenie wydanego na czas I wojny światowej Aliens Restriction Act. Cudzoziemcy mieli zatem nadal obowiązek rejestracji i nie wolno im było wykonywać określonych prac, na przykład pracy w służbie cywilnej, a także nie mogli zakładać i promować firm w szeroko rozumianym przemyśle. Uregulowane zostały zasady deportacji oraz wjazdu do Wielkiej Brytanii. Podkreślić należy, iż, w myśl tej ustawy za obywateli brytyjskich uznani zostali nie tylko mieszkańcy wysp brytyjskich, ale także mieszkańcy terytoriów zamorskich Wielkiej Brytanii, którzy byli zrównani w prawach $\mathrm{z}$ obywatelami dominium ${ }^{11}$. Niemniej jednak, jak podaje literatura przedmiotu, w praktyce w oparciu o Aliens Restriction Act obywatele terytoriów zamorskich traktowani byli jak cudzoziemcy i zdarzało się, iż odmawiano im prawa do równego traktowania $\mathrm{z}$ „wyspiarskimi” Brytyjczykami ${ }^{12}$.

W związku z narastającym problem imigrantów pochodzących z byłych kolonii brytyjskich, a w szczególności z dość liczną grupą tych, którzy wbrew założeniom urzędników brytyjskich nie zasymilowali się odpowiednio ${ }^{13}$, w 1962 roku został uchwalony The Commonwealth Immigrants $\mathrm{Act}^{14}$. W pierwszej kolejności akt ten

10 Aliens Restriction (Amendment) Act, 1919 [9\&10 GEO. 5. c. 92].

11 Forma ustrojowa kolonii zamorskiej w ramach imperium brytyjskiego, cieszącej się znaczną swobodą i niezależnością od kraju matki. S. Bożyk, M. Grzybowski, Systemy ustrojowe państw współczesnych, Białystok 2012, s. 377.

12 L. Tabili, We ask for British justice: Workers and racial difference in late imperial Britain, Ithaca, NY 1994, s. 2-20.

13 Głównie chodziło tu o zatrzymanie tak zwanych „czarnych imigrantów” z południowych Karaibów, Afryki, Azji, Indii i Pakistanu. G. Clayton i in., Textbook on immigration and asylum law, Oxford 2012, s. 10-11.

14 Commonwealth Immigrants Act 1962, 10\& 11 ELIZ. 2. CH. 21. 
wprowadził dywersyfikację obywateli Brytyjskiej Wspólnoty Narodów w oparciu o pochodzenie - więzy krwi (ius sanguinis) i od 1962 roku każdy, kto urodził się w Wielkiej Brytanii i Irlandii lub miał paszport wydany przez któryś z tych krajów, nie podlegał kontroli imigracyjnej. Obywatel każdego innego kraju już takiej kontroli podlegał i prawo wjazdu do Wielkiej Brytanii uzależnione było od uznania urzędnika imigracyjnego ${ }^{15}$.

Wbrew oczekiwaniom The Commonwealth Immigration Act z 1962 roku nie rozwiązał problemu niechcianej imigracji do Wielkiej Brytanii. Obywatele Tanzanii, Ugandy, Kenii oraz krajów azjatyckich, którzy nabyli obywatelstwo brytyjskie w procesie dekolonizacji, nie podlegali szczegółowej kontroli imigracyjnej i zaczęli masowo napływać do Wielkiej Brytanii, w efekcie czego w 1968 roku został uchwalony The Commonwealth Immigrants Act $1968^{16}$. Począwszy od 1968 roku z kontroli imigracyjnej zwolnieni byli wyłącznie ci obywatele Wielkiej Brytanii, którzy urodzili się na ziemi brytyjskiej, oraz ci, których choć jeden $\mathrm{z}$ rodziców lub dziadków urodził się na ziemi brytyjskiej (rozszerzona zasada ius soli) lub został adoptowany, zarejestrowany bądź naturalizowany w Wielkiej Brytanii ${ }^{17}$. Prawo imigracyjne zmieniało się zatem nadal, a Wielka Brytania dążyła do, można powiedzieć, absolutnej kontroli nad osobami wjeżdżającymi na jej terytorium.

\subsection{Rewolucja roku 1971}

Obowiązujący od końca II wojny światowej Alien Restriction Act, wielokrotnie nowelizowany, został w znacznej części zniesiony przez Immigration Act uchwalony w 1971 roku. Alien Restriction Act pozostaje nadal w mocy wyłącznie w zakresie zatrudniania obywateli

15 G. Clayton i in., Textbook on immigration and asylum law, dz. cyt., s. 10-11.

16 The Commonwealth Immigrants Act 1968, c. 9.

17 The Commonwealth Immigrants Act 1968, c. 9. 
państw trzecich na statkach pływających pod banderą brytyjską oraz w służbie cywilnej, a także penalizuje niektóre zachowania cudzoziemców, takie jak akcja sabotażowa skierowana przeciwko siłom zbrojnym Wielkiej Brytanii ${ }^{18}$.

Wielka nowelizacja prawa imigracyjnego, która miała miejsce w 1971 roku, wprowadziła nową definicję imigranta, uregulowała zasady wjazdu na teren Wielkiej Brytanii oraz ujednoliciła procedury deportacyjne i przepisy karne. Ustanowione zostały także nowe instytucje imigracyjne oraz Trybunał do spraw Imigrantów. Wprowadzone zostały do porządku brytyjskiego w odniesieniu do imigrantów zasada wolności zamieszkania i przemieszczania się oraz prawo do nienaruszania miru domowego i nietykalności osobistej. Ustawodawca wprowadził zasadę przyznawania zgody administracyjnej na pobyt czasowy na terenie Wielkiej Brytanii. Zniesiono kontrole graniczne w przypadku podróży na wyspę Man i wyspy położone w strefie Kanału La Manche. Podróże takie określone zostały jako podróże lokalne. Karane karą więzienia stało się nielegalne przekroczenie granicy brytyjskiej. Urzędnicy imigracyjni otrzymali także prawo do natychmiastowego aresztowania każdej osoby, która była podejrzana o nielegalne przebywanie na terytorium Wielkiej Brytanii. Obowiązek udowodnienia legalnego przekroczenia granicy został wprost nałożony na podejrzanego ${ }^{19}$.

Immigration Act z 1971 roku ${ }^{20}$ składa się z czterech części, z których dwie do 2002 roku obowiązywały w pełnym zakresie, jedna w ograniczonym, a jedna w ogóle została uchylona. W całości nie został jednak uchylony nawet przez nowo uchwalone prawo imigracyjne w 2014 roku, które w znacznej części derogowało Immigration Act

\footnotetext{
18 Aliens Restriction (Amendment) Act 1919 [9\&10 GEO. 5. c. 92].

19 Immigration Act 1971, c. 7.

20 M. Phelan, J. Gillespie, Immigration law handbook 2013, Oxford 2013, s. 3-9.
} 
Z 1971 roku. Pomimo licznych zmian pozostaje nadal, głównie w doktrynie, jedną z najważniejszych regulacji brytyjskich w przedmiocie prawa imigracyjnego ${ }^{21}$. Część pierwsza omawianej ustawy definiuje w sekcji 1 prawa podstawowe prawa imigracyjnego, jak prawo do zamieszkiwania i swobodnego przekraczania granicy dla każdego, kto ma obywatelstwo Wielkiej Brytanii ${ }^{22}$.

Tego samego dnia co Immigration Act 1971 wszedł w życie na terenie Wielkiej Brytanii Traktat Rzymski²3. Tym samym doszło do automatycznego rozszerzania dość wąskiej grupy osób uprzywilejowanych obywateli - o cudzoziemców, którzy w pierwotnym zamyśle twórców Immigration Act 1971 mieli być z niej wyłączeni. Tym samym prawa cudzoziemców (aliens) będących obywatelami państw Wspólnoty zostały automatycznie zrównane z prawami obywateli Wielkiej Brytanii. Podkreślić należy, iż pomimo swojej kompleksowości nie zostało uregulowane nawet w sposób szczątkowy prawo do otrzymania azylu na terenie Wielkiej Brytanii. W związku z powyższym prawem właściwym w przedmiocie określenia statusu osoby ubiegającej się o azyl pozostała Refugee Convention z 1951 roku $^{24}$. Omawiana ustawa

21 I. A. Macdonald QC, R. Toal, Macdonald's immigration law \& practice, vol. 1, London 2014, s. 24.

22 "All those who are in this Act expressed to have the right of abode in the United Kingdom shall be free to live in, and to come and go into and from, the United Kingdom without let or hindrance except such as may be required under and in accordance with this Act to enable their right to be established or as may be otherwise lawfully imposed on any person". Immigration Act 1971, c. 77.

23 Traktat ustanawiający Europejską Wspólnotę Gospodarczą, przyjęty w Rzymie W 1957 roku. Wielka Brytania przystąpiła do Europejskiej Wspólnoty Gospodarczej w 1972 roku i od 1 stycznia 1973 roku stała się oficjalnie jej członkiem. Traktat ustanawiający Europejską Wspólnotę Gospodarczą, traktat EWG - tekst pierwotny (przed konsolidacją) http://eur-lex.europa.eu/legal-content/PL/ TXT/?uri=URISERV\%3Axyoo23 (dostęp: 24.07.2016).

24 I. A. Macdonald QC, R. Toal, Macdonald's immigration law \& practice, dz. cyt., S. $12-14$. 
wprowadziła, jak zostało wskazane powyżej, nowe definicje do porządku prawnego. W pierwszej kolejności zniesiony został podział na obywateli Wielkiej Brytanii i resztę świata (british subjects and aliens). Do dwóch obowiązujących kategorii została dodana trzecia grupa określana jako częściowo/cząstkowo uprawnieni (partials). Zatem od 1973 roku prawo do swobodnego zamieszkania i przebywania na terenie Wielkiej Brytanii otrzymali: obywatele Wielkiej Brytanii i kolonii ${ }^{25}$, którzy nabyli obywatelstwo przez urodzenie, adopcję, naturalizację czy mający status rezydenta (british subjects); obywatele Wielkiej Brytanii i kolonii, których rodzice lub dziadkowie mieli obywatelstwo brytyjskie w chwili urodzenia się wnioskodawcy (partials); obywatele Wielkiej Brytanii i Kolonii, którzy od 5 lat zamieszkują na terenie Wielkiej Brytanii (obywatelstwo przez naturalizację); obywatele Brytyjskiej Wspólnoty Narodów, których rodzice nabyli obywatelstwo przez adopcję przed urodzeniem się wnioskodawcy (partals), oraz obywatele Brytyjskiej Wspólnoty Narodów, którzy zawarli związek małżeński z osobą uprawnioną do zamieszkania i przebywania na terenie Wielkiej Brytanii ${ }^{26}$. Ustawodawca odszedł

25 Termin „kolonie” jest tu użyty w znaczeniu brytyjskich kolonii zamorskich, które wchodziły w skład brytyjskiego imperium. British empire, https://www.britannica. com/place/British-Empire (dostęp: 24.07.2016).

26 "A person is under this Act to have the right of abode in the United Kingdom if: (a) he is a citizen of the United Kingdom and Colonies who has that citizenship by his birth, adoption, naturalisation or (except as mentioned below) registration in the United Kingdom or in any of the Islands; or (b) he is a citizen of the United Kingdom and Colonies born to or legally adopted by a parent who had that citizenship at the time of the birth or adoption, and the parent either (i) then had that citizenship by his birth, adoption, naturalisation or (except as mentioned below) registration in the United Kingdom or in any of the Islands; or (ii) had been born to or legally adopted by a parent who at the time of that birth or adoption so had it; or (c) he is a citizen of the United Kingdom and Colonies who has at any time been settled in the United Kingdom and Islands and had at that time (and while such a citizen) been ordinarily resident there for the 
zatem od postrzegania prawa do zamieszkania poprzez obywatelstwo, a przyjął zasadę prawa krwi (ius sanguinis) i prawo ziemi (ius soli).

Immigration Act 1971 ustalił zatem na nowo zasady wjazdu i przebywania na terytorium Wielkiej Brytanii. Przedmiotowe prawo ze zamianami obowiązywało do 1996 roku, kiedy to ponownie Wielka Brytania dokonała większej nowelizacji prawa imigracyjnego. Regulacje przedmiotowe zostaną omówione poniżej.

\subsection{Immigration Rules}

W Wielkiej Brytanii oprócz oficjalnego prawa imigracyjnego wprowadzanego do porządku prawnego w drodze ustawy, która była podpisywana przez króla i ogłaszana w dzienniku urzędowym, obowiązywały do 1971 roku także nieoficjalne regulacje określające zakres władzy urzędników imigracyjnych oraz zasady wjazdu na teren Wielkiej Brytanii. Te określane początkowo jako wytyczne czy regulacje wewnętrzne zasady stały się przedmiotem publicznej wiedzy w 1962 roku, kiedy to urzędnicy imigracyjni, wprowadzając w życie nowo uchwalony The Commonwealth Immigration Act, w praktyce nie stosowali zawartych w nim obostrzeń do obywateli Kanady, Australii i Nowej Zelandii ${ }^{27}$.

Przyjęcie Immigration Act w 1971 roku, w sekcji 1.4, która przyznała sekretarzowi stanu kompetencje (władzę dyskrecjonalną) do wprowadzenia Immigration Rules ${ }^{28}$, oficjalnie usankcjonowało Immigration

last five years or more; or (d) he is a Commonwealth citizen born to or legally adopted by a parent who at the time of the birth or adoption had citizenship of the United Kingdom and Colonies by his birth in the United Kingdom or in any of the Islands", Immigration Act 1971, c. 77.

27 M. Phelan, J. Gillespie, Immigration law handbook 2013, dz. cyt., s. 11.

28 „The rules laid down by the Secretary of State as to the practice to be followed in the administration of this Act for regulating the entry into and stay in the United Kingdom of persons not having the right of abode shall include provision 
Rules jako jedno ze źródeł prawa imigracyjnego. Omawiana wewnętrzna regulacja stanowi drugą część prawa imigracyjnego i jest na bieżąco nowelizowana w przypadku zmiany ustawy określającej ogólne normy prawa imigracyjnego. Nie jest to jednolity akt, jak Immigration Act, ale pod tym pojęciem rozumie się grupę dokumentów (niekiedy więcej niż 20 różnych) normujących poszczególne części prawa imigracyjnego w bardzo praktyczny sposób. Najprościej można porównać Immigration Rules do polskiego rozporządzenia, które w sposób konkretny, w oparciu o wytyczne zawarte w ustawie, doprecyzowuje ustawę, umożliwiając jej stosowanie w praktyce.

W 1994 roku zostały zmienione Immigration Rules wprowadzone na mocy Immigration Act z 1971 roku. W 1993 roku uchwalony został nowy Asylum and Immigration Appeals Act ${ }^{29}$. Obecnie obowiązują Immigration Rules znowelizowane przez decyzję Home Secretary w 2003 roku, a ostatnia nowelizacja miała miejsce w 2016 roku $^{30}$. Charakter prawny Immigration Rules jest bardzo trudny do określenia. Trudno też ustalić, jakie zasady i kiedy obowiązują w przypadku ciągłych zmian, brak bowiem norm kolizyjnych. Generalnie jednak orzeczenia sądowe zapadają w oparciu o kryterium, czy urzędnik imigracyjny przestrzegał zasad ustalonych w Immigration Rules, czy właśnie od nich odstąpił. Istotny jest także fakt, iż uchwalony w 1998 roku Human Rights Act zabrania stanowienia prawa w Wielkiej Brytanii przez organy władzy wykonawczej. Podkreślić należy, iż Immigration

for admitting (in such cases and subject to such restrictions as may be provided by the rules, and subject or not to conditions as to length of stay or otherwise) persons coming for the purpose of taking employment, or for purposes of study, or as visitors, or as dependants of persons lawfully in or entering the United Kingdom" Immigration Act 1971 c. 77.

Asylum and Immigration Appeals Act 1993, c. 23.

30 Immigration Rules: statement of changes, https://www.gov.uk/government/collections/immigration-rules-statement-of-changes. (dostęp: 25.07.2016). 
Rules tak naprawdę odzwierciedlają nurt polityczny i dostosowywane są raczej do panujących w chwili ich wydania trendów polityki imigracyjnej, a nie do aktu prawnego, który legł u podstaw ich wydania ${ }^{31}$.

\subsection{Nowelizacja procedury sądowej}

Najważniejszym jednak osiągnięciem reformy prawa imigracyjnego było wprowadzenie trybu odwoławczego od decyzji organów imigracyjnych i procedury obowiązującej przed Imigracyjnym Trybunałem Odwoławczym (Imigration Appeal Tribunal), która została wprowadzona Immigration Appeals Act w $1969 \mathrm{roku}^{32}$. Ustanowiony dwa lata wcześniej trybunał odpowiedzialny był za kontrolę orzeczeń administracyjnych, które zapadały w postępowaniu administracyjnym. Potrzeba ustanowienia dodatkowej kontroli nad decyzjami administracyjnymi pojawiła się po zawiśnięciu na wokandzie sądowej spraw: Re H. K. (an Infant) ${ }^{33}$, które wykazały, iż dochodzi do nadużyć po stronie organów imigracyjnych i błędnej wykładni przepisów imigracyjnych mogących mieć wpływ na poszanowanie praw

31 I. A. Macdonald QC, R. Toal, Macdonald's immigration law \& practice, dz. cyt., s. $29-39$.

32 Immigration Appeals Act 1969, c. 21.

33 Re H. K. (an Infant) [1967] 2 Q.B. 617 628-620. Obywatel Brytyjskiej Wspólnoty Narodów ma prawo wjazdu na teren Wielkiej Brytanii, nawet jeżeli nie ma ukończonych 16 lat. Odmowa wjazdu takiemu obywatelowi jest niezgodna z prawem i nie jest działaniem słusznym i sprawiedliwym. „A Commonwealth citizen had a right to be admitted to this country if he was (as this party claimed to be) under the age of 16 . The immigration officers were not satisfied that he was under 16 and refused him admission. Held: The Lord Chief Justice said that even if they were acting in an administrative capacity, they were under a duty to act fairly - meaning that they should give the immigrant an opportunity of satisfying them that he was under 16 . Part of the duty to provide a fair hearing includes disclosure to a party of prejudicial information, in order that the party may respond" http://swarb.co.uk/in-re-hk-an-infant-qbd-1967/ (dostęp: 15.01.2016). 
człowieka ${ }^{34}$. Ustawodawca brytyjski przyznał zatem prawo do wnoszenia odwołania do Trybunału każdemu, komu odmówiono prawa wjazdu do Wielkiej Brytanii lub nakazano wyjazd z jej terytorium. Prawo do odwołania przysługuje także każdemu, w stosunku do kogo wydano orzeczenie o ekstradycji. Można również odwołać się nie od samej decyzji nakazującej opuszczenie kraju czy ekstradycję, ale od zawartych w niej warunków i kraju przeznaczenia ${ }^{35}$. W zakresie prawa imigracyjnego działa także Asylum and Immigration Tribunal, w ramach którego działa Senior President of Tribunal ${ }^{36}$.

\subsection{Ewolucja prawa imigracyjnego Wielkiej Brytanii od 1988 do 2013 roku}

W 1988 roku dokonano zmiany prawa imigracyjnego poprzez ujednolicenie praw kobiet i mężczyzn oraz uregulowano sprawę małżeństw poligamicznych i wprowadzono szczególną ochronę kobiet, które zostały przymuszone do małżeństwa ${ }^{37}$. W następnych latach zostały wprowadzone kolejne regulacje normujące zasady przyznawania azylu w Wielkiej Brytanii oraz określania statusu uchodźcy politycznego. Doprecyzowane zostały także normy regulujące zasady pobierania i przechowywania takich informacji o osobach przekraczających granice Wielkiej Brytanii jak odciski palców czy próbki DNA ${ }^{38}$.

Kolejna wielka nowelizacja prawa imigracyjnego miała miejsce w 2002 roku poprzez uchwalenie Nationality, Immigration and

34 B. A. Hepple, Immigration Appeals Act 1969, „The Modern Law Review” vol. 32, no. 6 (Nov., 1969), s. 668-672.

35 Immigration Act 1971, c. 7.

36 I. A. Macdonald QC, R. Toal, Macdonald's immigration law \& practice, dz. cyt., s. 20 .

37 Immigration Act 1988, c. 14.

38 Immigration and Asylum Act 1999, c. 33. 
Asylum Act ${ }^{39}$. W jednym akcie prawnym zostały wprowadzone zmiany do dwóch oddzielnych do tego czasu ustaw: Immigration Act i British Nationality Act $1981^{40}$. W części pierwszej zostały doprecyzowane wymogi, jakie należy spełnić, aby uzyskać obywatelstwo brytyjskie. Został zatem wprowadzony wymógł sprawdzenia posiadanej wiedzy o kulturze i tradycji Wielkiej Brytanii oraz dobrej znajomości języka angielskiego. Ujednolicono katalog przesłanek, kiedy Secretary of State może daną osobę pozbawić obywatelstwa brytyjskiego, a także wprowadzono przesłankę negatywną pozbawienia obywatelstwa w przypadku osób, które nie mają drugiego obywatelstwa. Zmiany w prawie imigracyjnym objęły także rozszerzenie katalogu przestępstw, procedury postępowania $z$ osobą niemającą obywatelstwa innego kraju oraz procedury postępowania w przypadku osób, które złamały przepisy imigracyjne, przebywając na terytorium Wielkiej Brytanii ${ }^{41}$.

Jedną z ważniejszych nowelizacji prawa imigracyjnego był The Immigration, Asylum and Nationality Act z 2006 roku$^{42}$. Ustawodawca brytyjski zdecydował się bowiem na kompleksowe uregulowanie prawa imigracyjnego poprzez podzielenie aktu normatywnego na 6 części: Appelas (odwołania), Employer sanctions (sankcje dla pracodawców), Information (informacja), Claimants and applicants (powód i wnioskodawca), Miscellancous (naruszenia) i General (ogólne). W pierwszej kolejności zauważyć można, iż zastosowano odmienną od przyjętej technikę legislacyjną polegającą na uregulowaniu założeń podstawowych, wspólnych dla wszystkich części poprzednich, na końcu aktu prawnego. Określone zatem zostały zakres terytorial-

39 Nationality, Immigration and Asylum Act 2002, c. 41.

40 British Nationality Act 1981, c. 61.

41 Nationality, Immigration and Asylum Act 2002, c. 41.

42 Immigration, Asylum and Nationality Act z 2006, c. 6. 
ny obowiązywania nowego aktu prawnego oraz kwestie związane z odpłatnością. Urzędnicy imigracyjni uzyskali także poszerzone uprawnienia do zbierania, przechowywania i przekazywania zebranych danych osobowych i informacji o osobach przekraczających granice państwa. Urząd imigracyjny został również upoważniony do tworzenia bazy danych zawierającej także dane wrażliwe ${ }^{43}$. Poszerzono zakres odpowiedzialności pracodawców zatrudniających nielegalnych imigrantów oraz wprowadzono katalog kar i odpowiedzialności cywilnej. Ważne z punktu widzenia procedury i ochrony prawa było wprowadzenie nowych obostrzeń dla możliwości odwołania się od decyzji urzędnika imigracyjnego odmawiającego prawa do wjazdu na teren Wielkiej Brytanii członkom rodziny obywatela lub osobie, która uprzednio uzyskała zgodę na wjazd. Dość istotnym poszerzeniem uprawnień oficerów imigracyjnych było rozbudowanie katalogu okoliczności, w jakich mogli oni aresztować osobę, która miała zostać deportowana, a także okoliczności, w których można było pozbawić osobę obywatelstwa brytyjskiego lub prawa do zamieszkania. Wyraźnie zatem widać, iż nastąpiło znaczne poszerzenie zakresu kompetencji urzędników imigracyjnych praktycznie we wszystkich obszarach ich działalności. Natomiast prawa obcokrajowców i możliwości polemiki z niekorzystną decyzją oficera imigracyjnego zostały znacznie ograniczone. Następna tak rygorystyczna zmiana miała miejsce w 2014 roku $^{44}$.

Uchwalony rok później UK Border Acts $2007^{45}$ nie wszedł w życie od razu, ale uzależniony był od wcześniejszego zawarcia

43 Tym pojęciem określa się takie dane, jak: imię, nazwisko, imiona rodziców, kod DNA, dane biometryczne, państwowe numery indentyfikacyjne.

44 I. A. Macdonald QC, R. Toal, Macdonald's immigration law \& practice, dz. cyt., s. 28.

45 UK Borders Act 2007, c. 30. 
Commencement Orders ${ }^{46}$. Ponownie można zauważyć systematykę $\mathrm{w}$ technice legislacyjnej polegającą na podzieleniu aktu prawnego na siedem paralelnych części. Wprowadzone zmiany jeszcze bardziej poszerzyły kompetencje oficerów imigracyjnych poprzez przyznanie im np. prawa do zatrzymania do trzech godzin, do czasu przyjazdu policji, osoby podejrzanej o przeszłość kryminalną. Wprowadzono także prawo do tak zwanej „automatycznej deportacji” każdego skazanego prawomocnym wyrokiem karnym za zbrodnie i występki. W przypadkach opisanych w sekcji 32 do 39 deportacja była obowiązkowa i nie podlegała większej kontroli sądowej. Nowym uprawnieniem było też prawo do zatrzymania bez nakazu sądowego przewożonej nielegalnie gotówki i przekazanie jej albo policji w celu przeprowadzenia dalszego postępowania wyjaśniającego, albo do Secretary of State. Aresztowany (także bez nakazu sądowego) mógł zostać każdy, kto był podejrzany o podejmowanie działań mających na celu uzyskanie azylu w Wielkiej Brytanii czy to dla siebie, czy innej osoby. Poszerzono także katalog czynów, za które groziła odpowiedzialność karna, o przestępstwo z urzędnika/oficera imigracyjnego. Na mocy uk Border Acts 2007 utworzony został nowy urząd: Border and Immigration Inspectorate ${ }^{47}$. Nowe prawo imigracyjne dość szybko weszło w życie na obszarze całej Anglii, Walii i Irlandii Północnej, a w niepełnym zakresie w Szkocji. Ustawodawca brytyjski krok po kroku przyznaje oficerom imigracyjnym kolejne prerogatywy i penalizuje nowe czyny, w szczególności te popełnione przeciwko oficerom imigracyjnym. Przyjęte rozwiązania należy ocenić negatywnie, bowiem w interesie państwa nie

46 Commencement Orders jest elementem techniki legislacyjnej wprowadzającym w życie postanowienia całego aktu prawnego lub jego części w czasie późniejszym od daty wprowadzenia samego głównego aktu prawnego. Można porównać go do polskiego rozporządzenia.

47 I. A. Macdonald QC, R. Toal, Macdonald's immigration law \& practice, dz. cyt., s. $20-21$. 
leży przyznanie niekontrolowanej władzy dyskrecjonalnej oficerom imigracyjnym. Podważa to podstawowe prawa zawarte w Human Rights Act, który przyznaje każdemu niezależnie od pochodzenia prawo do obrony przed bezprawnym działaniem władzy państwowej.

The Borders, Citizenship and Immigration Act $2009^{48}$ jest efektem orzeczenia Sądu Apelacyjnego w sprawie Obed (Omerenna) v Secretary of State for the Home Department, w którym prawo do dokonywania zmian w zakresie raz przyznanego statusu prawnego w Wielkiej Brytanii będzie wymagało bezpośredniej i wyłącznej zgody Home Office. Przy okazji przyznano oficerom imigracyjnym prawo do pobierania i przechowywania odcisków palców tych osób, które podlegają lub mogą podlegać procedurze automatycznej deportacji ${ }^{49}$.

Kolejna znacząca zmiana prawa imigracyjnego w 2010 roku miała na celu dostosowanie prawa Wielkiej Brytanii do orzecznictwa Europejskiego Trybunału Praw Człowieka w Strasburgu i Europejskiego Trybunału Sprawiedliwości.

\section{Orzecznictwo Europejskiego Trybunału Praw Człowieka i jego wpływ na prawo imigracyjne Wielkiej Brytanii}

W 1998 roku uchwalony został The Human Rights Act, który wprowadzał do brytyjskiego porządku prawnego Konwencję Rady Europy o ochronie praw człowieka i podstawowych wolności, uchwaloną W 1950 roku $^{50}$. Wraz z implementowaniem Konwencji Wielka Brytania

48 Borders, Citizenship and Immigration Act 2009, c. 11.

49 I. A. Macdonald QC, R. Toal, Macdonald's immigration law \& practice, dz. cyt., London 2014, s. 22.

50 „An Act to give further effect to rights and freedoms guaranteed under the European Convention on Human Rights; to make provision with respect to holders 
przyznała swoim obywatelom prawo do wnoszenia skarg przed Europejski Trybunał Praw Człowieka z siedzibą w Strassburgu. Dzięki orzecznictwu Trybunału szczególnego znaczenia na gruncie brytyjskiego prawa imigracyjnego nabrał art. 8 Konwencji, który zapewnia każdemu prawo do posiadania rodziny, życia rodzinnego i życia prywatnego $^{51}$. Przedmiotowe prawo jest przyznane każdemu bez wyjątku, niezależnie od jego pochodzenia czy statusu ekonomicznego. Właśnie w oparciu o treść normy prawnej zawartej w tym artykule przed Europejskim Trybunałem Praw Człowieka zawisło szereg spraw, w których skarżący ubiegali się o poszanowanie ich prawa do posiadania rodziny. Wydając orzeczenia w takich sprawach jak Metock v Minister for Justice, Equality and Law Reform ${ }^{52}$ czy Abdulaziz et al

of certain judicial offices who become judges of the European Court of Human Rights; and for connected purposes", Human Rights Act, 1998, c. 42.

51 „(1) Everyone has the right to respect for his private and family life, his home and his correspondence. (2) There shall be no interference by a public authority with the exercise of this right except such as is in accordance with the law and is necessary in a democratic society in the interests of national security, public safety or the economic well-being of the country, for the prevention of disorder or crime, for the protection of health or morals, or for the protection of the rights and freedoms of others". European Convention of Human Rights, as amended by Protocols nos. 11 and 14 supplemented by Protocols Nos. 1, 4, 6, 7, 12 and 13, European Court of Human Rights, Council of Europe, Strasbourg 2013, s. 11.

52 "Article 3 (1) of Directive 2004/38 on the right of citizens of the Union and their family members to move and reside freely within the territory of the Member States amending Regulation No 1612/68 and repealing Directives 64/221, 68/360, $72 / 194,73 / 148,75 / 34,75 / 35,90 / 364,90 / 365$ and 93/96, which provides that the directive is to apply to all Union citizens who move to or reside in a Member State other than that of which they are a national, and to their family members as defined in point 2 of Article 2 of the directive who accompany or join them, must be interpreted as meaning that a national of a non-member country who is the spouse of a Union citizen residing in a Member State whose nationality he does not possess and who accompanies or joins that Union citizen benefits from the provisions of that directive, irrespective of when and where their 
v UK ${ }^{53}$, Trybunał uznał, iż Wielka Brytania dopuściła się naruszenia art. 8 Konwencji względem skarżących, poprzez odmówienie im prawa wjazdu lub nakazanie wyjazdu ze swojego terytorium w sytuacji, gdy rodzina skarżącego legalnie zamieszkiwała na terytorium Wielkiej Brytanii. Tym samym wystarczyło, żeby osoby ubiegające się o azyl lub prawo pobytu na terenie Wielkiej Brytanii wykazały, iż celem ich petycji jest połączenie rodzin, a ich podanie było rozpoznawane pozytywnie. Sądy podkreślały konieczność poszanowania przez organy imigracyjne prawa do życia osobistego, prawa do domu, prawa do posiadania rodziny oraz prawa do tajemnicy korespondencji. Sądownictwo wyraźnie wskazywało na naruszenie przez urzędy imigracyjne praw człowieka i niejednokrotnie zmieniało decyzje podejmowane przez organy imigracyjne, wyrażając zgodę na pobyt cudzoziemca na terenie Wielkiej Brytanii ${ }^{54}$.

marriage took place and of how the national of a non-member country entered the host Member State". Metock v Minister for Justice, Equality and Law Reform [2008] ECHR I-6241.

53 „The court was astute to recognize the right under international law of a state to control immigration into its territory. This right has been weighed against the degree of interference with the enjoyment of family life caused by the immigration restriction often not because this served a legitimate aim under article 8 (2) but because it acted as a free-standing restriction on the article 8 right. 'The Court recalls that, although the essential object of Article 8 is to protect the individual against arbitrary interference by the public authorities, there may in addition be positive obligations inherent in an effective 'respect' for family life. However, especially as far as these obligations are concerned, the notion of 'respect' is not clear cut: having regard to the diversity of the practices followed and the situations obtaining in the Contracting States, the notion's requirements will vary considerably from case to case". Abdulaziz et al v U K (1985) 7 EHRR 471.

54 The Supreme Court, Decided Cases, https://www.supremecourt.uk/decided-cases/ (dostęp: 15.01.2016). 


\section{Zmiany prawa imigracyjnego w latach 2014-2016}

Uchwalenie pierwszej ustawy regulującej zasady wjazdu obcokrajowców na terytorium Wielkiej Brytanii podyktowane było strachem przed napływem na terytorium Wielkiej Brytanii zbyt dużej liczby osób obcych kulturowo i językowo. Imigranci pochodzili zazwyczaj z ubogich rodzin, polegali na opiece socjalnej, jaką gwarantowało państwo brytyjskie, i poszukiwali szybkiego zarobku. Lokalna ludność postrzegała ich jako źródło chorób i kryminalizacji społeczeństwa. Dokonując analizy obecnych zmian w prawie imigracyjnym, wprowadzanych sukcesywnie od 2014 roku, możemy zauważyć, iż te same obawy, które istniały na przełomie XIx i xx wieku, towarzyszą i dziś społeczeństwu brytyjskiemu.

Podstawowym aktem prawnym, który na nowo zamknął Wielką Brytanię na świat i dokonał ponownej rewolucji w systemie imigracyjnym, jest Immigration Act z 2014 roku ${ }^{55}$. Przedstawiciele doktryny uznali przedmiotową ustawę za jedną z najbardziej agresywnych ${ }^{56}$ zmian prawa imigracyjnego w Wielkiej Brytanii. Uregulowania prawne zawarte $\mathrm{w}$ przedmiotowej ustawie wprowadzane są stopniowo, a ostatnia regulacja ma wejść w życie w 2017 roku $^{57}$.

Poczynając zatem od 2015 roku, Wielka Brytania na nowo zaczęła określać zasady wjazdu i przebywania imigrantów na swoim terytorium.

55 Immigration Act 2014, c. 22.

56 Ian Macdonald wprost stwierdza, iż podstawowym i głównym celem Immigration Act z 2014 jest stworzenie nieprzyjaznego, wrogiego środowiska dla tych spośród wjeżdżających do Wielkiej Brytanii, którzy wykraczają poza normy prawne ustanowione w państwie brytyjskim. „The Immigration Act 2014 was expressly designed to creat an ever more hostile environment for migrants who abuse the system..." Macdonald A. I. QC, Toal R., Macdonald's immigration law \& practice, dz. cyt., s. 22.

57 Macdonald A. I. QC, Toal R., Macdonald's immigration law \& practice, dz. cyt., s. 22,178 . 
Zaostrzeniu uległy nie tylko procedury kwalifikacji wjeżdżających. Odebrane zostały im także pewne istotne prawa, jak prawodo wniesienia odwołania od decyzji oficera imigracyjnego czy prawo do uzyskania zgody na wniesienie apelacji od decyzji. Zmianie uległy zatem Immigration Rules, uchwalone w 1994 roku $^{58}$, które stanowią wykładnię i uzupełnienie Immigration Laws. Najważniejsza zmiana, jaka została wprowadzona, dotyczy podstaw do ubiegania się o prawo stałego pobytu na terenie Wielkiej Brytanii. Do kwietnia 2016 roku prawo ubiegania się o stały pobyt będą mieć wyłącznie te osoby, które udowodnią roczny dochód w wysokości powyżej 35 tys. GBP. Obecnie nie będzie miała zatem znaczenia długość pobytu czy inne związki (np. rodzinne) z Wielką Brytanią, bowiem decydować będzie wyłącznie czynnik ekonomiczny. W tym momencie osoby ubiegające się o uzyskanie azylu na terenie Wielkiej Brytanii nie mogą być obywatelami lub rezydentami żadnego państwa należącego do Unii Europejskiej, chyba że istnieją specjalne okoliczności uzasadniające taki wniosek ${ }^{59}$. Obowiązują także nowe procedury identyfikacji imigrantów poprzez wprowadzenie prawa urzędników imigracyjnych do pobierania próbek DNA. Wprowadzono nowe przesłanki odebrania statusu uchodźcy oraz wprowadzono nowe zawody do sytemu punktowego, będącego podstawą do udzielenia zgody na pobyt na terenie Wielkiej Brytanii, tzW. TIER 2 CZy TIER 3. Inną modyfikacją jest także zmiana testu z podstawowej znajomości języka angielskiego w przypadku ubiegania się o obywatelstwo Wielkiej Brytanii na test zaawansowanej znajomości angielskiego. Wartą wspomnienia zmianą jest także prawo odmowy

58 Home Secretary, Immigration rules, London 1994.

59 Dla przykładu można tu wskazać sprawę polskiego Roma, mieszkańca Kielc, który domagał się udzielania mu azylu jako osobie zagrożonej dyskryminacją i wykluczeniem społecznym w Polsce. A. Tanner, The Roma of Eastern Europe: still searching for inclusion. 1 may 2005, http://www.migrationpolicy.org/article/ roma-eastern-europe-still-searching-inclusion (dostęp: 25.01.2016). 
wjazdu na teren Wielkiej Brytanii dziecku, jeżeli osoba sponsorująca w ocenie urzędnika imigracyjnego może stanowić dla niego zagro$\dot{z ̇ e n i e}^{60}$. Zaznaczyć należy, iż zmiany te dotyczą nie tylko aplikacji składanych po kwietniu 2016 roku, ale wszystkich podań o uzyskanie prawa stałego pobytu złożonych także w listopadzie 2015 roku.

\section{Podsumowanie}

Podsumowując przedmiotowe rozważania, można śmiało powiedzieć, iż historia zatoczyła koło, i te same obawy przed imigrantami, które towarzyszyły Brytyjczykom w 1905 roku, kiedy to wprowadzono pierwsze ograniczenia dotyczące wjazdu cudzoziemców na teren Wielkiej Brytanii, istnieją także obecnie. Po okresie znaczącego odprężenia i otwarcia się Wielkiej Brytanii na imigrantów, szczególnie tych pochodzących z Unii Europejskiej, aktualnie ponownie można zauważyć znaczne zamknięcie się na cudzoziemców i prowadzenie polityki utrudniającej napływ imigrantów do Wielkiej Brytanii. Dodatkowo, czego nie było uprzednio, rząd brytyjski przyznał urzędnikom imigracyjnym prawo do weryfikowania statusu cudzoziemca w każdym czasie i miejscu. Wzależności od przypadku oficerowie mają prawo nakazania natychmiastowego opuszczenia kraju cudzoziemcowi, a nie tylko prawo do odmowy wjazdu do Wielkiej Brytanii. Dane statystyczne pokazują, iż obecnie populacja Wielkiej Brytanii wynosi ponad 70 mln mieszkańców ${ }^{61}$ - jest to znacznie więcej, niż może unieść zdolność ekonomiczna kraju.

60 House of Commons, Statement of changes in immigration rules, London 2016, s. $4-38$.

61 Britain's „70 million” debate, http://www.migrationobservatory.ox.ac.uk (dostęp: 20.02.2016). 


\section{Summary}

Immigration law in United Kingdom. The overview

British Empire on the end of XIX century convert the half of the know world. The Brits were present on each continent and they market their territory with introducing they laws and made the aboriginal peoples of this land they subject. Soon they face the problem over the citizenship question and migration to their homeland. How ever, as they expected to be welcome on the new land they were not so willing welcome to the newcomers to the United Kingdom. The public opinion demand form the government to introduce new laws, which would prevent newcomers to settle and obtain the same privileges as the British people already have. After the creation of the European Union the British politic change when it comes to immigration policy and large number of the Polish people immigrate to United Kingdom and decided to settle there. However recently the British politic change once again the legislative go around the circle, and in 2015 the British government introduce the new immigration policy restraining the foreigners rights in United Kingdom.

Keywords: immigration, officer, border, asylum, foreigner 